\title{
Pappen-Verarbeitung und
}

\section{Papiermaché}

\author{
II. Teil \\ der \\ Praxis der Pappen-Verarbeitung
}

Unter Mitarbeit von Fachleuten

herausgegeben von

Walter Hess

Mit 19 Figuren im Text und 1 Beilage

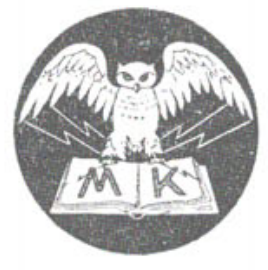

Berlin W

Verlag von M. Krayn

1924 
Copyright 1924 by M. Krayn, Berlin W. 10.

Alle Rechte vorbehalten,

namentlich das der Uebersetzung. 